\title{
The Use of Roughing Filters in Water Purification
}

\author{
*K. M. Adel ${ }^{1}$, M. S. Negm ${ }^{2}$, M. H. Abdel Razik ${ }^{3}$ and E. S. Wahb ${ }^{4}$ \\ ${ }^{1}$ Faculty of Eng., Ain Shams Univ., Cairo \\ ${ }^{2}$ Sanitary\& Environment Engineering, Faculty of Eng., Ain Shams Univ., Cairo \\ ${ }^{3}$ Sanitary\& Environment Engineering, Faculty of Eng., Ain Shams Univ., Cairo \\ ${ }^{4}$ Sanitary\& Environment Engineering, Faculty of Eng., Ain Shams Univ., Cairo
}

Received: 5-01-2014

Accepted: 20-1-2014

Published:01-03-2014

*Corresponding author: khaled.adel@dargroup.com

T: 002-01004456731

\begin{abstract}
The objective of this research is to investigate the performance of various roughing filter

configurations as pre-treatment for filtration process. UFRS has recorded the highest efficiency among the four RF configurations followed by the HFRS, DFRS, HFRS-IP (Hz roughing filter with inclined plates). Results revealed that the UFRS recorded average turbidity removal efficiency of $76.64,83.02$ and $87.88 \%$ at $\mathrm{ROF} 0.7 \mathrm{~m} / \mathrm{h}, 0.5 \mathrm{~m} / \mathrm{h}$ and $0.3 \mathrm{~m} / \mathrm{h}$ respectively. DFRS recorded average turbidity removal efficiency of $74.90,76.19$ and $78.59 \%$ at ROF $0.7 \mathrm{~m} / \mathrm{h}, 0.5 \mathrm{~m} / \mathrm{h}$ and $0.3 \mathrm{~m} / \mathrm{h}$ respectively. HFRS recorded average turbidity removal efficiency of $73.33,76.80$ and $80.73 \%$ at $\mathrm{ROF} 0.7 \mathrm{~m} / \mathrm{h}, 0.5 \mathrm{~m} / \mathrm{h}$ and $0.3 \mathrm{~m} / \mathrm{h}$ respectively. HFRS-IP recorded average turbidity removal efficiency of $69.88,72.87$ and $74.10 \%$ at ROF $0.7 \mathrm{~m} / \mathrm{h}, 0.5 \mathrm{~m} / \mathrm{h}$ and $0.3 \mathrm{~m} / \mathrm{h}$ respectively. All configuration handled $30 \mathrm{NTU}$ influent turbidity without problems.
\end{abstract}

Key Words: Roughing filter, gravel filter, upflow, downflow, Horizontal Flow and inclined plates.

\section{Introduction}

Various pre - treatment alternatives are used to improve raw water quality in water treatment plant prior to filtration process. Because of its simplicity and sustainability, roughing filters are recommended for small and rural communities where slow sand filter is used.

The roughing filters can be applied as a pretreatment for water purification or to increase the efficiency of the existing plain sedimentation tanks. This system is suitable for low cost water pre- treatment in rural areas and highly turbid storm water treatment. Roughing filters are generally either:

1) A large compartment filled with successive layers of filter media decreasing in size in the direction of flow.

2) Multiple compartments connected in series, each filled with one media size.
Water flow through the filter can be either horizontal or vertical. Figure 1 shows three examples of roughing filters, including, a downflow roughing filter in series (DRFS), an upflow roughing filter in series (URFS) and a horizontal roughing filter in (HRF).

Literature Review Wegelin (1987) (1) assessed particle removals over 20 - to 40 -cm horizontal filter segments using a model (kaolinite clay) suspension $(200 \mathrm{mg} / \mathrm{L}$ initial influent concentration) and used multivariate regression analysis to develop empirical equations that related filter design parameters (media size and hydraulic loading rate) to the initial steady-state, particle size specific filter coefficient and the particle size-specific ultimate filter volume assuming a constant density of 1.15 $\mathrm{g} / \mathrm{cm} 3$ for deposited solids. Evaluation of particle 
straining and cake filtration was neglected in this study.

Galvis, et al. (1996) (2) compared the performance of HRF, HRFS (Horizontal Roughing Filter in Series), and URFS with natural waters in Cali, Columbia and found that removal efficiencies were better for URFS with little or no difference between the HRF and HRFS, despite the HRF having a filter length of $7.1 \mathrm{~m}$ compared to $4.3 \mathrm{~m}$ for the other two configurations. Also, less wash water was needed to restore efficiency in the URFS.

Collins (1994) (3) extended the work of Wegelin and assessed particle removals over 90-cm downflow filter segments using kaolinite clay $(1,000 \mathrm{mg} / \mathrm{L}$ TSS initial influent concentration) and algae (influent concentration not provided) suspensions. The influence of humic acid and calcium addition in kaolinite clay suspensions on removal efficiencies was also investigated. Collins (1994) found in laboratory experiments with kaolinite clay and kaolinite clay + algae that removal efficiencies in the first $60-\mathrm{cm}$ of HRFs compared to URFs were better for larger media sizes (7.94 $-11.11 \mathrm{~mm})$ but worse for smaller media sizes $(2.68-4.83 \mathrm{~mm})$. El-Taweel, GE and Ali, GH(2000) (4), In a previous Egyptian study evaluated a filter media consisted of three layers of gravel ranked top among six of the media tested, showing $84-100 \%$ removal for chlorophyll 'a', green algae, blue-green algae, diatoms, total algal count, bacterial count (at 22 and $37^{\circ} \mathrm{C}$ ).

Tamar, L., (2008) (5) , A pilot HRF at Ghanasco Dam in Tamale, NRG was conducted using three $7 \mathrm{~m}$ tubes filled with three sizes of granite gravel, local gravel, and broken pieces of ceramic filters arranged by decreasing size. The granite gravel removed $76 \%$ and $84 \%$ of the influent turbidity according to the settling test and pilot HRF data respectively.

\section{Experimental Setup:}

This experiment is a part of multi stage filtration (MSF) pilot plant built in Giza WTP. Figure 2 show the Giza WTP flow chart. Figure 3 shows the pilot plant and pointing out the positions of collecting samples.

The turbidity of influent and effluent water was determined during the experimental period of this study for the four RF configurations. Various rates of filtration and influent turbidity tested for each of RF configuration.

The experiment run was applied for 14 days of operation with 11days of actual readings (three reading every day) and 3 days for cleaning the media after each change of the turbidity influent and adjusting the experiment apparatus for the new configuration.

Four RF (roughing filters) configurations were tested and evaluated:

-Upflow Roughing Filters in Series (URFS) illustrated in Figure 4.

-Downflow Roughing Filters in Series (DRFS) illustrated in Figure 5.

-Horizontal flow roughing filters in Series (HRFS) illustrated in Figure 6.

-Horizontal flow filters in Series with inclined plates (HRFS-IP) illustrated in Figure 7.

Each configuration was operated under different operation condition of hydraulic loading rates and influent Turbidity for a period of two weeks. Table 1 shows the configuration runs.

Experiments were conducted using one media size packed in each of the four filter configuration; this provided the opportunity to evaluate simultaneously the filter performance for one media size, three hydraulic loading rates and three initial influent concentrations over four filter configurations. Every test reading is the mean value of a three experiments done with the same configuration.

Raw water is extracted from the common delivery pipe of intake pump at Giza WTP, and discharge to a constant head tank feeding the pilot plant.

Normally the River Nile turbidity is below10 NTU. However, water turbidity increased to measure the behavior of the RF during peak loading conditions. Settled sludge is added from the main sedimentation tank in Giza WTP to increase the turbidity level.

For this study the filter chambers is packed with gravel media with the characteristics shown in Table 2 .

\section{Results and Discussions:}

The laboratory results will be analyzed and discussed for the four RF configurations. The analysis will show the effect of the filtration rate and influent turbidity verses the efficiency.

The averages of every three readings are taken into considerations. The results are illustrated for the four roughing filter configurations as following: -First table and figure show the influent and effluent turbidity at various rate of filtration used. -Second figure shows the efficiency of turbidity removal calculated.

Comparison between Four Roughing Filter:

The average efficiencies for the four configurations are illustrated in the Figure 16 for every filtration rate. The result show that the at rate of filtration $0.3 \mathrm{~m} / \mathrm{h}$ and $0.5 \mathrm{~m} / \mathrm{h}$ the UFRS recorded the highest 
efficiency followed with the HFRS, DFRS then HFRS-IP.

In the final filtration rate $0.7 \mathrm{~m} / \mathrm{h}$ the HFRS recorded lower than DFRS but the above mentioned rank remain the same the UFRS recorded the highest followed with DFRS, HFRS and finally the HFRS_IP.

The HFRS-IP recorded the lowest efficiency considered (69.88\%-74.1\%) but this configuration gives us new way to treat water. Due to cost problems and experiment schedule, only one HFRS-IP configuration was tested.

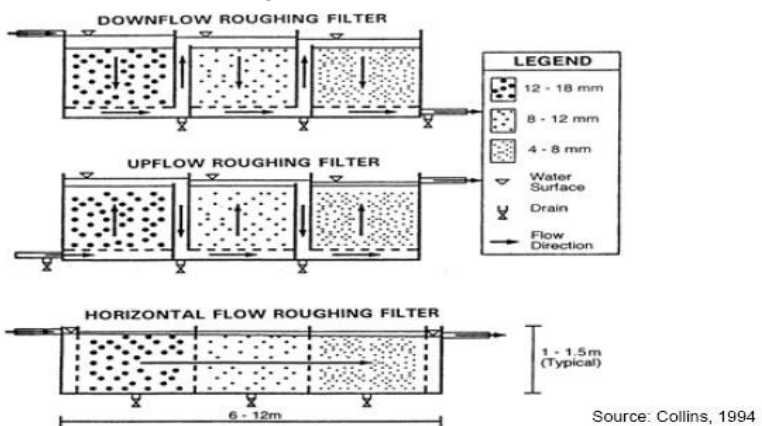

Figure (1): Typical configurations used in roughing filtration

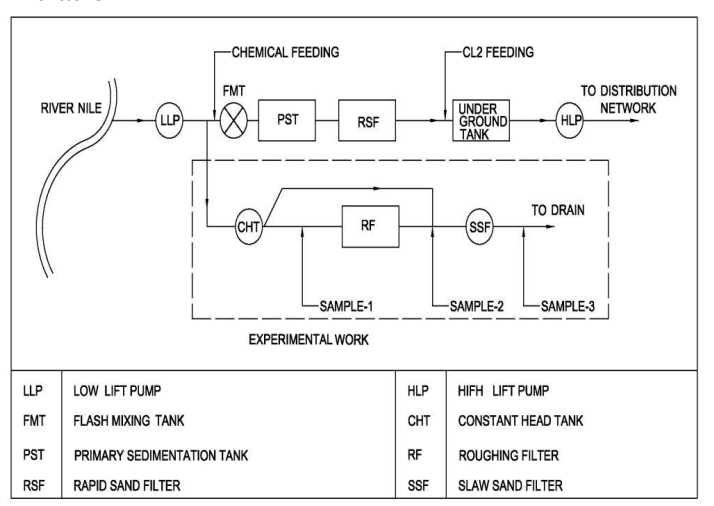

Figure (2): Giza WTP \& experimental work flowchart.

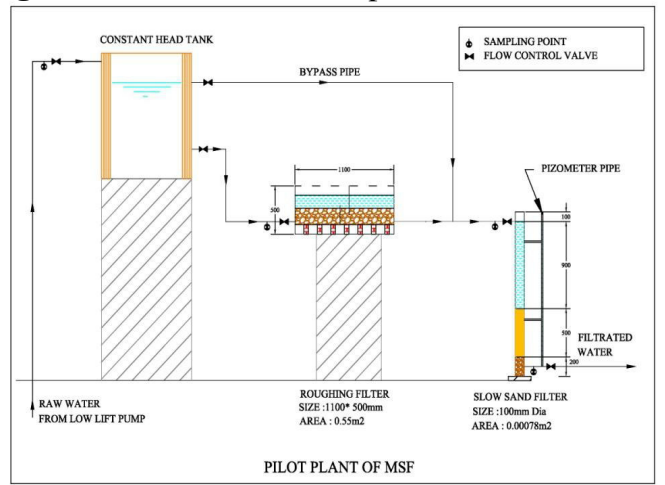

Figure (3): MSF pilot plant

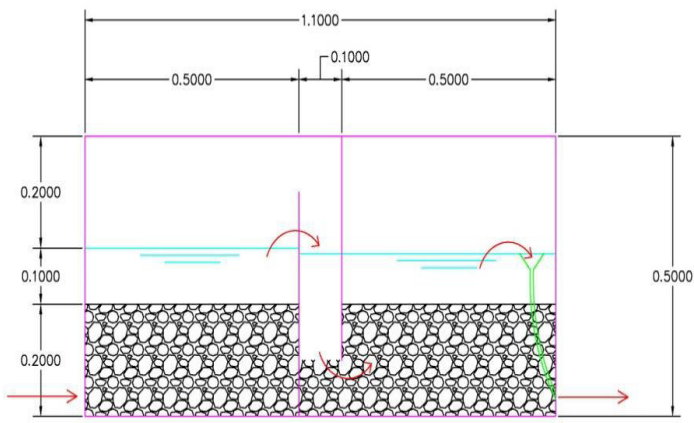

Figure (4): Upflow roughing filter

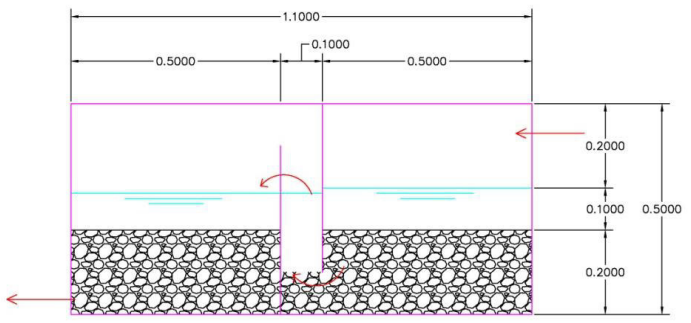

Figure (5):Downflow roughing filter

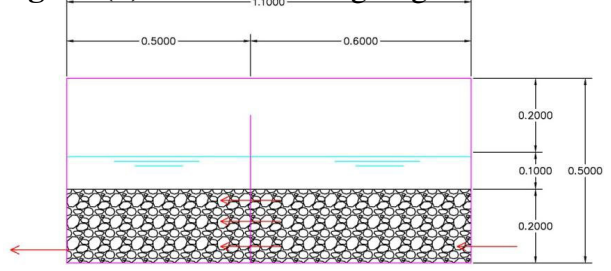

Figure (6): Horizontal flow roughing filter

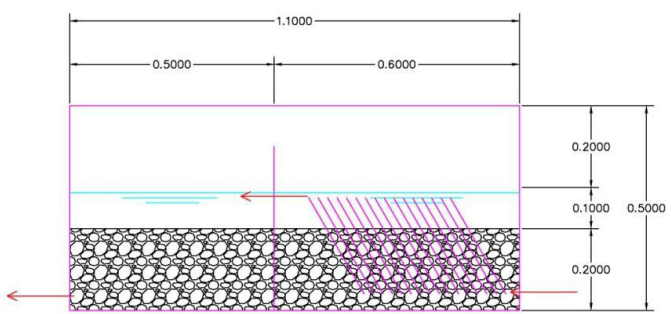

Figure (7): HRFS-IP filter configuration 


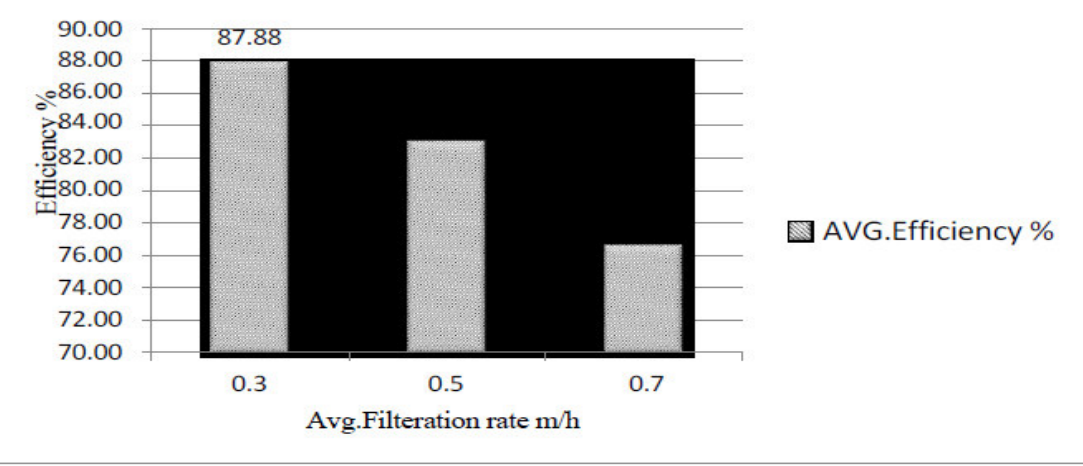

Figure (8) - UFRS efficiency vs. average rate of filtration

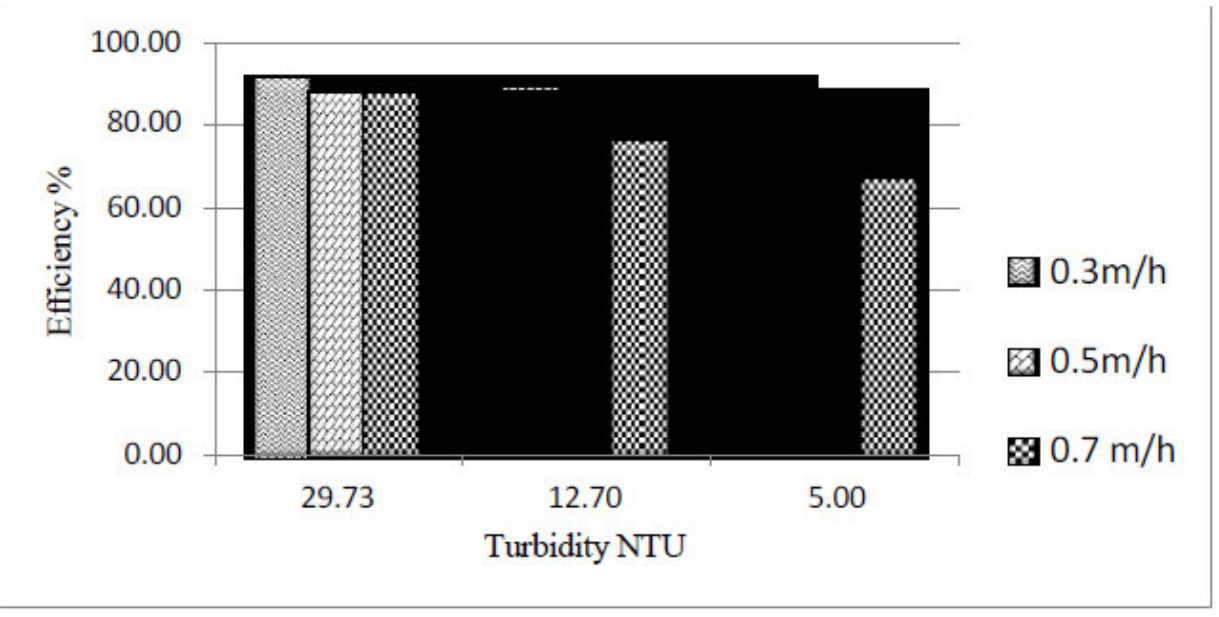

Figure (9) - UFRS efficiency vs. influent turbidity

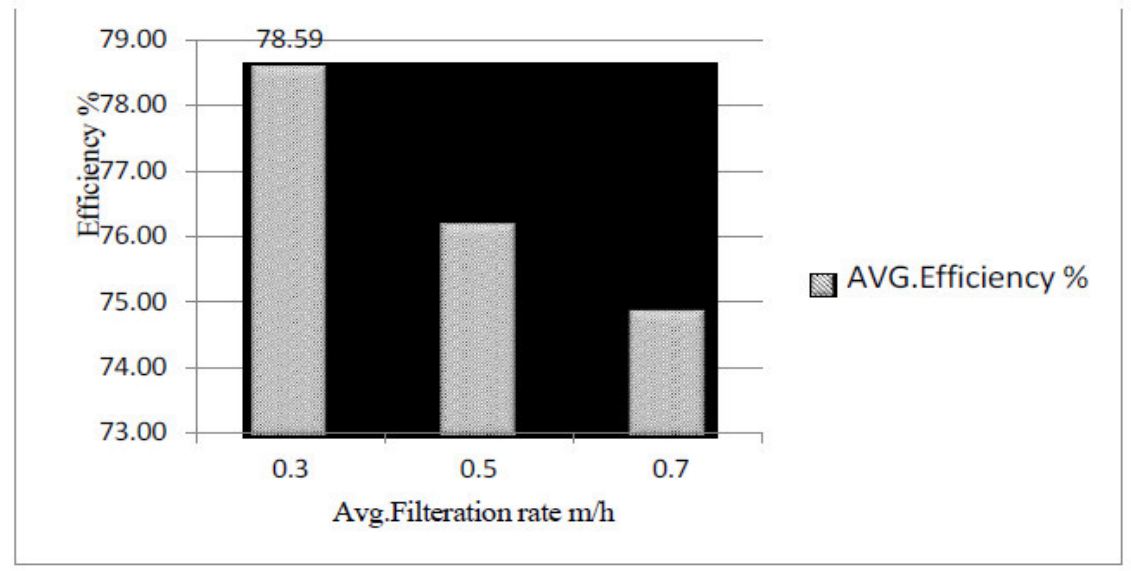

Figure (10) - DFRS efficiency vs. average rate of filtration 


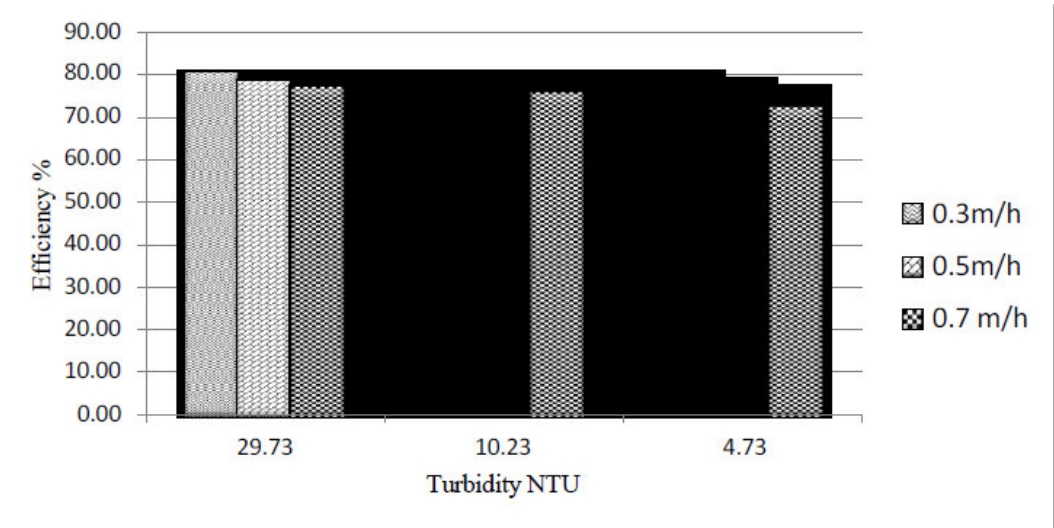

Figure (11) - DFRS efficiency vs. influent turbidity

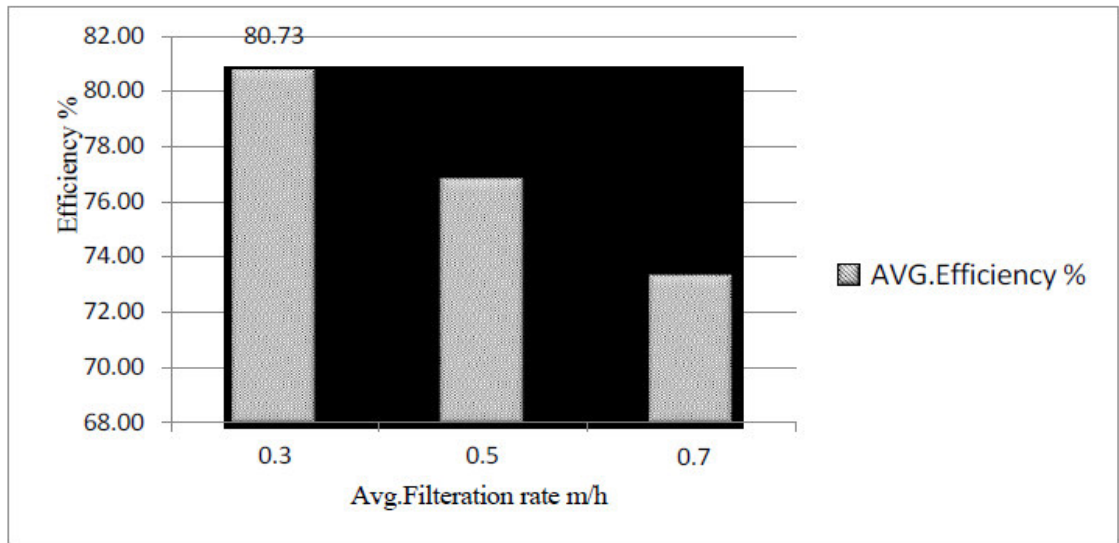

Figure (12) - HFRS efficiency vs. average rate of filtration

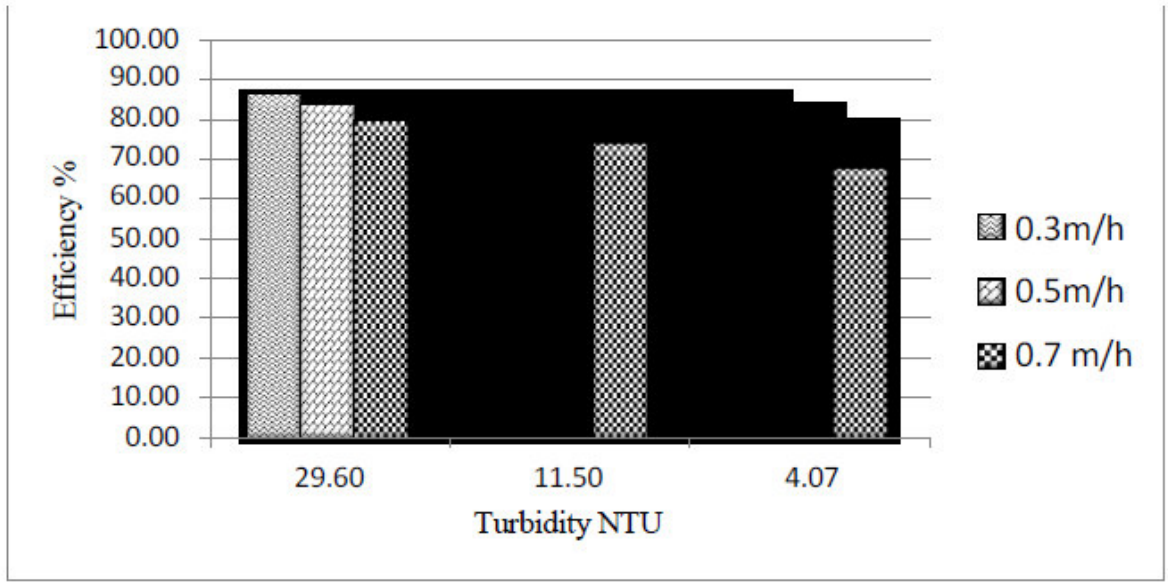

Figure (13) - HFRS efficiency vs. influent turbidity 


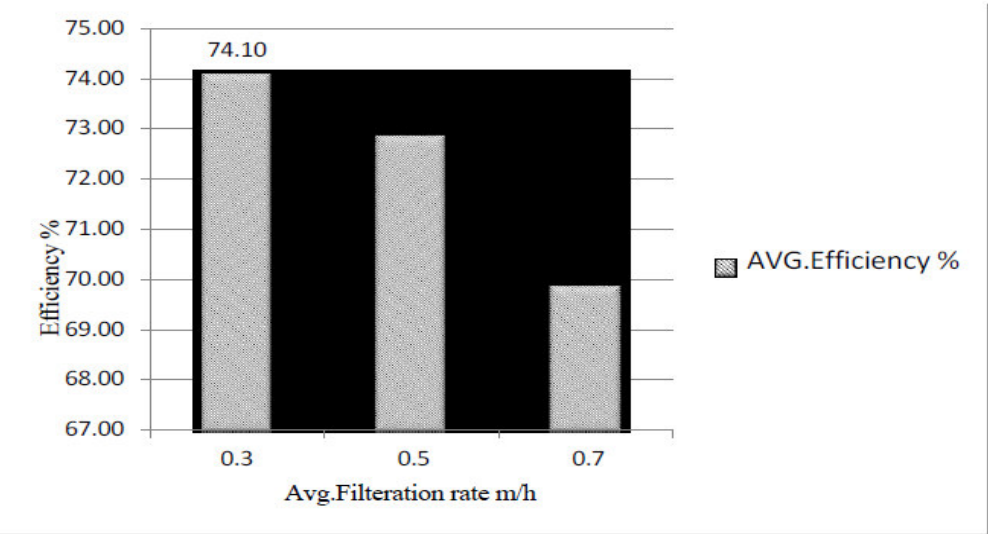

Figure (14) - HFRS-IP efficiency vs. average rate of filtration

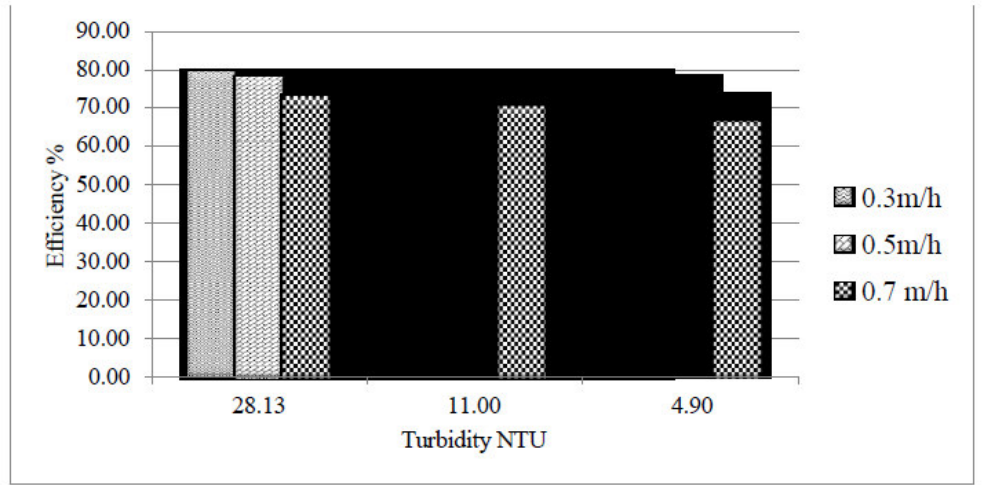

Figure (15) - HFRS-IP efficiency vs. influent turbidity

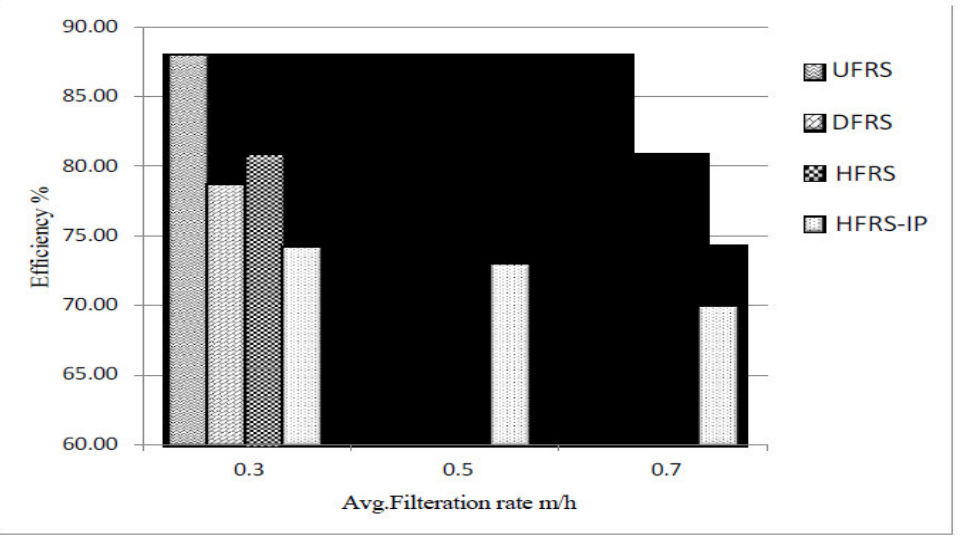

Figure (16) - Comparison between Four Roughing Filter Configuration 


\begin{tabular}{|c|c|c|c|c|c|c|}
\hline \multirow[t]{2}{*}{ Filter configuration } & \multirow{2}{*}{$\begin{array}{c}\text { Hydraulic } \\
\text { Loading Rate } \\
\text { Range }(\mathbf{m} / \mathbf{h r})\end{array}$} & \multirow{2}{*}{$\begin{array}{l}\text { Average } \\
\text { Media size } \\
(\mathrm{mm})\end{array}$} & \multicolumn{3}{|c|}{ Initial Turbidity (NTU) } & \multirow[t]{2}{*}{ Duration } \\
\hline & & & $\begin{array}{c}4 \\
\text { low }\end{array}$ & $\begin{array}{l}1030 \\
\text { medium }\end{array}$ & high & \\
\hline URFS & $0.3-0.7$ & 15 & $\nabla$ & 口 & 四 & 2 weeks \\
\hline DRFS & $0.3-0.7$ & 15 & $\square$ & $\square$ & 口 & 2 weeks \\
\hline HRFS & $0.3-0.7$ & 15 & $\nabla$ & $\square$ & 田 & 2 weeks \\
\hline HRFS-IP & $0.3-0.7$ & 15 & $\underline{\square}$ & $\underline{\square}$ & 四 & 2 weeks \\
\hline
\end{tabular}

Table (1) - Configuration Runs for Turbidity Removal on Clean Media

\begin{tabular}{|c|c|c|c|c|}
\hline $\begin{array}{c}\text { Average } \\
\text { diameter }\left(\mathbf{d}_{\mathbf{a}}\right) \mathbf{m m}\end{array}$ & $\begin{array}{c}\text { Minimum } \\
\text { diameter }\left(\mathbf{d}_{\min }\right) \mathbf{m m}\end{array}$ & $\begin{array}{c}\text { Maximum } \\
\text { diameter }\left(\mathbf{d}_{\max }\right) \mathbf{m m}\end{array}$ & D60/D10 & Porosity \\
\hline 15 & 5 & 25 & 1.2 & 0.46 \\
\hline
\end{tabular}

Table (2) - Size distribution of media used in roughing filter

\begin{tabular}{|c|c|c|c|c|c|}
\hline $\begin{array}{c}\text { Raw Data } \\
\text { Groups }\end{array}$ & $\begin{array}{c}\text { Experiment Run } \\
\text { Number }\end{array}$ & $\begin{array}{c}\text { Avg. Filtration } \\
\text { Rate m/h }\end{array}$ & $\begin{array}{c}\text { Avg. RF Influent } \\
\text { NTU }\end{array}$ & $\begin{array}{c}\text { Avg. RF } \\
\text { Effluent NTU }\end{array}$ & $\begin{array}{c}\text { Avg. Efficiency } \\
\%\end{array}$ \\
\hline $1-2-3$ & 1 & 0.3 & 29.73 & 2.67 & 91.03 \\
\hline $4-5-6$ & 2 & 0.3 & 12.70 & 1.40 & 88.72 \\
\hline $7-8-9$ & 3 & 0.3 & 5.00 & 0.80 & 83.89 \\
\hline $10-11-12$ & 1 & 0.5 & 26.73 & 3.37 & 87.44 \\
\hline $13-14-15$ & 2 & 0.5 & 11.97 & 1.90 & 84.10 \\
\hline $16-17-18$ & 3 & 0.6 & 4.80 & 1.10 & 77.52 \\
\hline $19-20-21$ & 1 & 0.7 & 29.23 & 3.67 & 87.41 \\
\hline $22-23-24$ & 2 & 0.7 & 10.57 & 2.50 & 75.97 \\
\hline $25-26-27$ & 3 & 0.7 & 5.40 & 2.00 & 66.55 \\
\hline
\end{tabular}

Table (3) - The UFRS readings

\begin{tabular}{|c|c|c|c|c|c|}
\hline $\begin{array}{c}\text { Raw Data } \\
\text { Groups }\end{array}$ & $\begin{array}{c}\text { Experiment Run } \\
\text { Number }\end{array}$ & $\begin{array}{c}\text { Avg. Filtration } \\
\text { Rate m/h }\end{array}$ & $\begin{array}{c}\text { Avg. RF Influent } \\
\text { NTU }\end{array}$ & $\begin{array}{c}\text { Avg. RF Effluent } \\
\text { NTU }\end{array}$ & $\begin{array}{c}\text { Avg. } \\
\text { Efficiency \% }\end{array}$ \\
\hline $1-2-3$ & 1 & 0.3 & 29.73 & 5.87 & 80.28 \\
\hline $4-5-6$ & 2 & 0.3 & 10.23 & 2.23 & 78.52 \\
\hline $7-8-9$ & 3 & 0.3 & 4.73 & 1.07 & 76.96 \\
\hline $10-11-12$ & 1 & 0.5 & 30.03 & 6.50 & 78.33 \\
\hline $13-14-15$ & 2 & 0.5 & 11.33 & 2.63 & 76.94 \\
\hline $16-17-18$ & 3 & 0.5 & 4.03 & 1.07 & 73.30 \\
\hline $19-20-21$ & 1 & 0.7 & 29.83 & 6.87 & 76.87 \\
\hline $22-23-24$ & 2 & 0.7 & 10.10 & 2.47 & 75.65 \\
\hline $25-26-27$ & 3 & 0.7 & 3.93 & 1.10 & 72.17 \\
\hline
\end{tabular}

Table (4) - The DFRS readings

\begin{tabular}{|c|c|c|c|c|c|}
\hline $\begin{array}{c}\text { Raw Data } \\
\text { Groups }\end{array}$ & $\begin{array}{c}\text { Experiment Run } \\
\text { Number }\end{array}$ & $\begin{array}{c}\text { Avg. Filtration } \\
\text { Rate m/h }\end{array}$ & $\begin{array}{c}\text { Avg. RF } \\
\text { Influent NTU }\end{array}$ & $\begin{array}{c}\text { Avg. RF } \\
\text { Effluent NTU }\end{array}$ & $\begin{array}{c}\text { Avg. } \\
\text { Efficiency \% }\end{array}$ \\
\hline $1-2-3$ & 1 & 0.3 & 29.60 & 4.13 & 86.00 \\
\hline $4-5-6$ & 2 & 0.3 & 11.50 & 2.27 & 80.36 \\
\hline $7-8-9$ & 3 & 0.3 & 4.07 & 0.97 & 75.82 \\
\hline $10-11-12$ & 1 & 0.5 & 29.07 & 4.97 & 83.07 \\
\hline $13-14-15$ & 2 & 0.5 & 11.23 & 2.50 & 77.08 \\
\hline $16-17-18$ & 3 & 0.5 & 4.63 & 1.33 & 70.25 \\
\hline $19-20-21$ & 1 & 0.7 & 30.50 & 6.37 & 79.12 \\
\hline $22-23-24$ & 2 & 0.7 & 11.50 & 2.87 & 73.56 \\
\hline $25-26-27$ & 3 & 0.7 & 4.10 & 1.33 & 67.31 \\
\hline
\end{tabular}

Table (5) - The HRFS readings 


\begin{tabular}{|c|c|c|c|c|c|}
\hline $\begin{array}{c}\text { Raw Data } \\
\text { Groups }\end{array}$ & $\begin{array}{c}\text { Experiment Run } \\
\text { Number }\end{array}$ & $\begin{array}{c}\text { Avg. Filtration } \\
\text { Rate m/h }\end{array}$ & $\begin{array}{c}\text { Avg. RF } \\
\text { Influent NTU }\end{array}$ & $\begin{array}{c}\text { Avg. RF } \\
\text { Effluent NTU }\end{array}$ & $\begin{array}{c}\text { Avg. } \\
\text { Efficiency \% }\end{array}$ \\
\hline $1-2-3$ & 1 & 0.3 & 28.13 & 5.80 & 79.39 \\
\hline $4-5-6$ & 2 & 0.3 & 11.00 & 2.90 & 73.55 \\
\hline $7-8-9$ & 3 & 0.3 & 4.90 & 1.50 & 69.35 \\
\hline $10-11-12$ & 1 & 0.5 & 32.17 & 7.17 & 77.72 \\
\hline $13-14-15$ & 2 & 0.5 & 11.37 & 3.13 & 72.34 \\
\hline $16-17-18$ & 3 & 0.5 & 5.60 & 1.70 & 68.53 \\
\hline $19-20-21$ & 1 & 0.7 & 30.00 & 8.10 & 73.00 \\
\hline $22-23-24$ & 2 & 0.7 & 9.87 & 2.93 & 70.31 \\
\hline $25-26-27$ & 3 & 0.7 & 5.17 & 1.73 & 66.34 \\
\hline
\end{tabular}

Table (6) - The HRFS-IP readings

\begin{tabular}{|c|c|c|c|l|}
\hline & \multicolumn{4}{|c|}{ Configuration Avg. Efficiency \% } \\
\hline ROF m/h & UFRS & DFRS & HFRS & HFRS-IP \\
\hline 0.3 & 87.88 & 78.59 & 80.73 & 74.10 \\
\hline 0.5 & 83.02 & 76.19 & 76.80 & 72.87 \\
\hline 0.7 & 76.64 & 74.90 & 73.33 & 69.88 \\
\hline
\end{tabular}

Table 7-The four RF configuration average efficiency 


\section{Conclusions:}

The following conclusions can be withdrawn from the study:-

1.UFRS has recorded the highest efficiency among the four RF configurations.

Followed by the HFRS, DFRS, and HFRS-IP. In addition results revealed that the UFRS was able to remove 76.64 to $87.88 \%$ turbidity for the evaluated media sizes and hydraulic loading rates.

2. Removal efficiency is improved with slower hydraulic loading rate. For example experiments UFRS conducted at rate of filtration $0.3 \mathrm{~m} / \mathrm{h}$ recorded efficiency $11.24 \%$ better than experiments conducted at $0.7 \mathrm{~m} / \mathrm{h}$. 3. All RF configuration handled influent Turbidity up to 30NTU without any major problems. Effluent turbidity increased slightly with increase influent turbidity but was within acceptable range for the subsequent SSF.

For example experiments DFRS conducted at 30 NTU were up to $3.66 \%$ better than experiments conducted at 4 NTU.

4. The four RF configuration average efficiency are as follows: Table 7

\section{Recommendations:}

Based on the results obtained from the experimental program executed in this research, the following recommendations from this study could be illustrated:-

1. The RF should be applied as a pre-treatment for water purification. The system is suitable for low cost water pre- treatment in the rural areas and highly turbid storm water treatment.

2. The RF technology can be one of the ways to increase efficiency of the existing plain sedimentation tanks without any need to add chemicals.

3. Covered filter is recommended to avoid growth of algae and avoid filter clogging. The experiment shows that at slower filtration rates the algae grow faster and the clogging will happen eventually.

\section{References}

1. Wegelin, M. Bolller, M. and Schertenleib, R, "Particle removal by horizontal-flow roughing filtration" Aqua, vol. 2: pp. 80-90, (1987).

2. Galvis, G. Latorre, J. Ochoa, A. and Visscher, $\mathrm{J}$, "Comparison of horizontal and upflow roughing filtration" in Advances in Slow Sand \& Alternative Biological

Filtration, ed. Graham, N \& Collins, R 1996, Wiley \& Sons, Chichester, England, (1996).

3. Collins, MR. Westersund, CM, Cole, JO, and Roccaro, JV, "Evaluation of roughing

filtration design variables" American Water Works Association Research

Foundation and American Water Works Association, (1994).

4. El-Taweel, GE and Ali, GH, "Evaluation of roughing and slow sand filters for

water treatment", Water, Air, and Soil Pollution, vol. 120, pp. 21-8. (2000).

5. Tamar,L., "Pilot Study of Horizontal Roughing Filtration in Northern Ghana as Pre-treatment for Highly Turbid Dugout Water". Master's thesis. Massachussets Institute of Technology, Boston, Massachusetts, (2008). 